\title{
Antioxidant activity, fatty acid profile and tocopherols of Tamarindus indica L. seeds
}

\author{
Atividade antioxidante, perfil de ácidos graxos e tocoferóis de sementes de Tamarindus indica L.
}

\author{
Débora Maria Moreno LUZIA ${ }^{1}$, Neuza JORGE ${ }^{1 \star}$
}

\begin{abstract}
This study aimed to characterize Tamarindus indica L. seeds regarding its composition and to evaluate its antioxidant potential, fatty acid profile and content of tocopherols. In order to obtain the extract, the dried and crushed seeds were extracted with ethanol for 30 minutes in a 1:3 seeds: ethanol ratio under continuous stirring at room temperature. After that, the mixtures were filtered and subjected to roto-evaporation at $40{ }^{\circ} \mathrm{C}$ in order to determine, through direct weighing, the dry matter yields of the extracts. According to the results, Tamarindus indica $\mathrm{L}$. seeds showed high content of total carbohydrates (71.91\%) and offered relevant content and antioxidant activity of phenolic compounds. Tamarindus indica L. seeds oil presents high oxidative stability (15.83 hours) and significant total tocopherol content $\left(57.77\right.$ mg.kg $\left.{ }^{-1}\right)$, besides presenting a higher percentage of unsaturated fatty acids - the main component being linolenic (59.61\%), which is considered an essential fatty acid.
\end{abstract}

Keywords: Tamarindus indica L.; oils; gas-chromatography.

\section{Resumo}

Este trabalho teve como objetivo caracterizar as sementes de Tamarindus indica L. quanto à sua composição centesimal, além de avaliar o potencial antioxidante e o perfil dos ácidos graxos e o teor de tocoferóis. Para a obtenção do extrato, as sementes desidratadas e trituradas foram extraídas com álcool etílico por 30 minutos, na proporção de 1:3 de sementes: álcool etílico, sob agitação contínua, em temperatura ambiente. Em seguida, as misturas foram filtradas e submetidas ao rotoevaporador a $40{ }^{\circ} \mathrm{C}$ com vistas a determinar, por pesagem direta, os rendimentos em matéria seca dos extratos. De acordo com os resultados obtidos, as sementes de Tamarindus indica L. demonstraram elevado teor de carboidratos totais $(71,91 \%)$, além de apresentarem relevante atividade antioxidante e teor de compostos fenólicos totais. O óleo das sementes de Tamarindus indica L. apresentou alta estabilidade oxidativa (15,83 horas), conteúdo significativo de tocoferóis totais $\left(57,77 \mathrm{mg} \cdot \mathrm{kg}^{-1}\right)$, além de destacar maior porcentagem de ácidos graxos insaturados, sendo o principal componente o linoleico (59,61\%), considerado ácido graxo essencial.

Palavas-chave: Tamarindus indica L.; óleos; cromatografia gasosa.

\section{Introduction}

Many natural compounds found in fruits, grains and vegetables present antioxidant activity. Among the most important natural antioxidants are the phenolic compounds (flavonoids, phenolic acids and tannins), nitrogenous compounds (alkaloids, amino acids, peptides, amines and chlorophyll byproducts), carotenoids, tocopherols and ascorbic acid (AMAROWICZ et al., 2004). Tamarindus indica L. seeds are important sources of antioxidant activity as 2-hydroxy-3', 4'-dihydroxyacetophenone, methyl 3,4-dihydroxybenzoate, 3,4-dihydroxyphenylacetate and (-)-epicatechin, in addition to oligomeric proanthocyanidins (SIDDHURAJ, 2007).

Many agro-industrial byproducts contain phenolic compounds with potential application as antioxidant in food (TORRES et al., 2002). Some antioxidant compounds have been identified in fruit seeds, but there are few studies reporting antioxidant activity in seeds of subtropical and tropical fruits (BOCCO et al., 1998; JAYAPRAKASHA; SINGH; SAKARIAH, 2001).
Researches have been carried out because of the great medical and nutritional interest on omega- 3 and omega- 6 fatty acid in foods. Fatty acids that compose foods are of great importance, especially the polyunsaturated ones from omega-3 and omega- 6 families, which contribute with many benefits to the human body. The omega- 3 family (PUFA $\omega 3$ ) comprises the $\alpha$-linolenic essential fatty acid (C18: $3, \omega 3)$, from which, through elongation and dessaturation, eicosapentaenoic acid

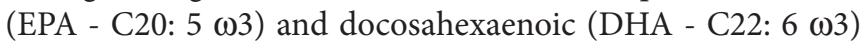
are generated (BELDA; POURCHET-CAMPOS, 1991). The omega- 6 family comprises linoleic essential fatty acid, which can originate arachidonic acid.

Epidemiologically, omega-3 polyunsaturated fatty acids present a beneficial effect on preventing many types of cancer (CURI et al., 2002). Omega-6 exerts an important physiological role as a powerful mediator of inflammation and it has a beneficial effect on the immune system (POMPÉIA; PROCÓPIO; CURI, 1999).

Received 23/9/2009

Accepted 18/1/2010 (004428)

${ }^{1}$ Departament of Engineering and Food Technology, São Paulo State University - UNESP, Cristóvão Colombo, 2265, CEP 15054-000, Jd. Nazareth, São José do Rio Preto, SP, Brazil, E-mail: njorge@ibilce.unesp.br

${ }^{*}$ Corresponding author 
Tocopherols are naturally present in most vegetable oils. There are four types: $\alpha$-, $\beta$-, $\gamma$-and $\delta$-tocopherol; with $\alpha$-tocopherol being the most abundant in foods and the one with the greatest biological activity as vitamin E (KAMAL-ELDIN; APPELQVIST, 1996). The antioxidant activity of tocopherols is mainly due to their ability of donating phenolic hydrogen to lipid free radicals, inhibiting oxidation. However, it was noticed that the activity of tocopherols in vitro also depends on many other possible parallel reactions that are drastically affected by their concentrations, by temperature and light, by the type of substrate, and by other chemical species acting as pro-oxidant and synergist in the system (JUNG; MIN, 1990).

Tamarindus indica $\mathrm{L}$. belongs to the Leguminosae family (Caesalpinioideae). It is originally from Africa and is grown in humid or arid, tropical and subtropical regions with an average annual temperature of $25^{\circ} \mathrm{C}$; it requires great light intensity and is sensitive to cold. In Brazil, production is located in the North and Northeast. About 150-250 kg of fruit can be produced per year from 4 to 6 years after planting (12 to 18 t.ha $^{-1}$ ) (BAHIA, 2009).

The fruit has an elongated pod, 5 to $15 \mathrm{~cm}$ long, with dark brown bark; woody and brittle seed in numbers from 3 to 8 , surrounded by a brown pulp containing sugar, tartaric, acetic and citric acids.

It is one of the most important fruits used as spice and food source in Africa (TSUDA et al., 1994). Its sweet and sour pulp and fibrous texture is used for preparing sweets, ice cream, liquors, soft drinks and concentrated juices. Practically all parts of the plant are used in folk medicine and it has numerous therapeutic applications in humans, including its usage as digestive, tranquilizer, laxative and expectorant (KOMUTARIN et al., 2004).

This detailed study of the composition of Tamarindus indica $\mathrm{L}$. seeds will bring contribution to health professionals not only regarding adequate dietary orientation, but also raising data that might be used in tables regarding proximate composition and fatty acids of lipid fraction. The obtainment of data on the composition of Brazilian foods has improved in order to gather updated, reliable information that is suitable to the national reality.

Thus, this study aimed to characterize the seeds of Tamarindus indica L. regarding its composition and to evaluate its antioxidant potential, fatty acid profile and content of tocopherols.

\section{Materials and methods}

\subsection{Materials}

\section{Raw material}

After being received, Tamarindus indica L. seeds acquired from Noemia candy industry, in Engenheiro Schmidt, SP, from plants located in Southeastern Brazil, tropical climate region.

The seeds were lightly rinsed with distilled water to remove waste from flesh and soluble sugars, after that, they were placed in an incubator at $35^{\circ} \mathrm{C}$ for 24 hours to reduce moisture content, and then, they were homogenized in a mixer for further analysis - performed in triplicate.

\section{Obtaining Tamarindus indica L. extract}

The dehydrated and crushed seeds were extracted with ethyl alcohol for 30 minutes, at a 1:3 seed: ethyl alcohol ratio, under continuous agitation at room temperature. Then the mixture was filtered and subjected to rotary evaporation under pressure reduced to $40^{\circ} \mathrm{C}$ in order to determine, through direct weighing, the dry matter yield in the extract.

\subsection{Methods}

\section{Determination of proximate composition}

Analytical determinations of moisture, lipid and ashes in seeds were performed according to the official methods of AOCS (AMERICAN... , 1993). The proteins were determined by the Kjeldahl method described by AOAC (ASSOCIATION..., 1995) and the total carbohydrates were quantified by the difference of the value obtained with the sum of moisture, lipids, proteins and ashes.

\section{Determination of DPPH free radical scavenging}

This procedure was described by Brand-Williams, Cuvelier and Berset (1995). An ethanolic solution was prepared at a concentration of $500 \mu \mathrm{g} \cdot \mathrm{mL}^{-1}$ of Tamarindus indica L. seeds extract. Each sample of this solution $(0.3 \mathrm{~mL})$ was added to $2.7 \mathrm{~mL}$ of DPPH (1,1-Diphenyl-2-picrylhydrazyl) solution $\left(40 \mu \mathrm{g} \cdot \mathrm{mL}^{-1}\right)$ in different concentrations $(5,10,25,50,125,250$ and $400 \mu \mathrm{g} \cdot \mathrm{mL}^{-1}$ ). After a 30 minutes reaction, the absorbance was read at $515 \mathrm{~nm}$ and converted into percentage of antioxidant activity (AA), using the following Equation 1:

$\mathrm{AA}(\%)=100-\left\{\left[\left(\mathrm{Abs}_{\text {sample }}-\mathrm{Abs}_{\text {white }}\right) \times 100\right] / \mathrm{Abs}_{\text {control }}\right\}$

A control was done with $2.7 \mathrm{~mL}$ of DPPH and white was performed with $0.3 \mathrm{~mL}$ of ethanolic solution of the extract and $2.7 \mathrm{~mL}$ of ethanol for each concentration.

This methodology allows the determination of the $\mathrm{EC}_{50}$ $\left(\mu \mathrm{g} \cdot \mathrm{mL}^{-1}\right)$, that is defined as the sufficient concentration of natural extract to obtain $50 \%$ of maximum effect antioxidant activity, estimated at 100\%, by linear regression.

\section{Total phenolic compounds}

The quantification of total phenolic compounds was determined by spectrophotometry, using the Folin-Ciocauteu reagent, according to the methodology described by Singleton and Rossi (1965).

In this procedure, $100 \mu \mathrm{L}$ of natural extract solution were pipetted in test tubes and then $500 \mu \mathrm{L}$ of Folin-Ciocauteau reagent were added. After that, $1.5 \mathrm{~mL}$ of saturated solution of sodium carbonate $20 \%$ and $6 \mathrm{~mL}$ of distilled water were added.

This mixture remained at rest for 2 hours at room temperature, and absorbance was measured at $765 \mathrm{~nm}$. Gallic 
acid was used to make the calibration curve and the result was expressed in milligrams of gallic acid equivalents per gram of extract $\left(\mathrm{mg}_{\mathrm{g}} \mathrm{g}^{-1}\right)$.

\section{Oxidative stability}

This measurement was determined by the method proposed by AOCS Cd 12b-92 (AMERICAN..., 1993) using Metrohm 743 Rancimat $^{\oplus}$, under the following conditions: $3.0 \mathrm{~g}$ of oil, air flow of $20 \mathrm{~L} /$ hour, temperature of $100{ }^{\circ} \mathrm{C}$ and $60 \mathrm{~mL}$ of distilled water in flasks containing the electrodes. The Rancimat ${ }^{\oplus}$ method is based on the production of volatile degradation products, determined by the changes observed in the electrical conductivity of distilled water.

Through this method, a curve is automatically registered during the reaction and the oxidative stability is determined in hours.

\section{Fatty acid profile by gas chromatography}

The fatty acid methyl esters (FAME) were obtained according to the procedure described by Hartman and Lago (1973).

The chromatographic analysis of FAMEs was performed using a Varian 3900 GC gas chromatograph (Walnut Creek, USA), equipped with a flame-ionization detector, a split injector and an auto-sampler. Compounds were separated using a CP-Sil 88 fused silica capillary column (50 m length, $0.25 \mathrm{~mm}$ internal diameter and $0.20 \mu \mathrm{m}$ film thickness).

The column temperature programming was initially held at $50{ }^{\circ} \mathrm{C}$ for 2 minutes, heated at $4{ }^{\circ} \mathrm{C} /$ minute up to $240{ }^{\circ} \mathrm{C}$ and maintained isotherm for 20.5 minutes. The temperatures used in the injector and in the detector were 230 and $250{ }^{\circ} \mathrm{C}$, respectively. Samples of $1 \mu \mathrm{L}$ were injected adopting a split ratio of 1:30. Hydrogen was the carrier gas having a linear speed of $30 \mathrm{~mL} /$ minute.

Fatty acids were identified by comparing their retention times of pure standards of fatty acids methyl esters to those compounds separated from the samples; they were quantified by performing area normalization (\%). A mixture made of 37 fatty acid methyl esters (Supelco, Bellefonte, USA), from C4: 0 to C24: 1, with purity between 99.1 and $99.9 \%$, was used as standard.

\section{Tocopherols}

The AOCS Ce 8-89 (AMERICAN..., 1997) method was applied in order to determine the content of tocopherols. The analysis was performed using high performance liquid chromatography (HPLC) with fluorescence detector, according to the following conditions: silica column of $250 \times 4,6 \mathrm{~mm}$, with $5 \mu \mathrm{m}$ pore, $1.2 \mathrm{~mL} / \mathrm{minute}$ flow, excitation wavelength at $290 \mathrm{~nm}$ and emission at $330 \mathrm{~nm}$. A mixture of $99.5 \% \mathrm{n}$-hexane and $0.5 \%$ isopropanol, HPLC purity, was used as mobile phase.

Around $1 \mathrm{~g}$ of the oil sample was weighed in $25 \mathrm{~mL}$ volumetric flask, this volume was completed with n-hexane with a degree of purity for HPLC. The volumetric flask was covered with aluminum foil to prevent degradation of the isomers by the action of light. Next, the volumetric flask was agitated in the mechanical stirrer for 1 minute. After that, the filtering was done in a $0.45 \mu \mathrm{m}$ filter and injected into the chromatograph. The mixing of $\alpha$-, $\beta$-, $\gamma$-, $\delta$-tocopherol with purity between 99.0 and $99.9 \%$, was used as a standard, which contained all isomers, was diluted from concentrated standards and injected.

Results of injections were recorded in "Galaxie" computer software. Concentration values were calculated based on the area of reading peak of excitement, and were expressed in values of each separate counterpart, in terms of $\mathrm{mg} \cdot \mathrm{kg}^{-1}$.

\section{Results and discussion}

Table 1 shows the mean and standard deviation of the proximate composition of Tamarindus indica L. seeds. According to the results, the fresh seeds of Tamarindus indica L. had a moisture content of $47.60 \%$. After dehydration in an incubator at $35^{\circ} \mathrm{C}$ for 24 hours to obtain the extract, the moisture content of seeds is now $9.78 \%$. Although they demonstrated low values of lipids and ashes, 3.41 and $2.16 \%$ respectively, there was a considerable amount of protein $(12.74 \%)$ and a high amount of total carbohydrates (71.91\%).

Table 2 indicates the percentage yield and the maximum percentage of antioxidant activity $\left(\mathrm{AA}_{\text {maximum }}\right)$, the $\mathrm{EC}_{50}\left(\mu \mathrm{g} \cdot \mathrm{mL}^{-1}\right)$ and the content of total phenolic compounds $\left(\mathrm{mg} \cdot \mathrm{g}^{-1}\right)$ of Tamarindus indica L. seeds extract.

The yield of dry extract was $38.20 \%$. According to Fernandes et al. (2002) this percentage may vary depending on fruit species and technique used for extraction.

The value of $\mathrm{EC}_{50}$, obtained by linear regression to Tamarindus indica L. extract (Figure 1), showed high coefficient of determination $\left(\mathrm{R}^{2}=0.9565\right)$. The values of maximum

Table 1. Proximate composition of Tamarindus indica L. seeds, expressed in percentage.

\begin{tabular}{lrc}
\hline \multicolumn{1}{c}{ Macronutrients } & Mean & Standard deviation \\
\hline Humidity & 9.78 & 0.05 \\
Lipids & 3.41 & 0.01 \\
Proteins & 12.74 & 0.06 \\
Ashes & 2.16 & 0.02 \\
Total carbohydrates & 71.91 & 0.10 \\
\hline
\end{tabular}

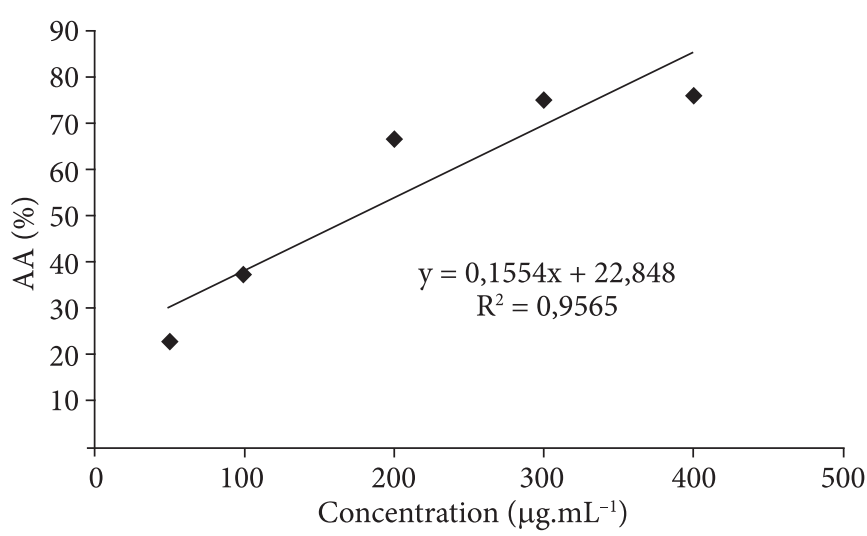

Figure 1. Linear regression of the antioxidant activity of Tamarindus indica L. seeds extract. 
Table 2. Determination of yield, antioxidant activity and total phenolic compounds of Tamarindus indica L. seeds extract.

\begin{tabular}{lc}
\hline \multicolumn{1}{c}{ Determinations } & Extract \\
\hline Yield $(\%)$ & 38.20 \\
$\mathrm{AA}_{\text {maximum }}(\%)$ & 75.93 \\
$\mathrm{EC}_{50}\left(\mu \mathrm{g} \cdot \mathrm{mL}^{-1}\right)$ & 204.72 \\
Total phenolic compounds $\left(\mathrm{mg} . \mathrm{g}^{-1}\right)^{*}$ & 49.30
\end{tabular}

$\mathrm{EC}_{50}$ is defined as the sufficient concentration to obtain $50 \%$ of maximum effect, estimated at $100 \%$. ${ }^{*} \mathrm{mg}$ of gallic acid equivalents per gram of extract.

Table 3. Profile of fatty acids present in the lipid fraction of Tamarindus indica L. seeds.

\begin{tabular}{lrc}
\hline \multicolumn{1}{c}{ Fatty acids (\%) } & Mean & Standard deviation \\
\hline Palmitic (C16:0) & 10.07 & 0.09 \\
Estearic (C18:0) & 2.82 & 1.77 \\
Oleic (C18:1 n9) & 14.33 & 0.03 \\
Linoleic (C18:2 n6) & 59.61 & 0.12 \\
Araquidic (C20:0) & 1.82 & 0.03 \\
Behenic (C22:0) & 4.13 & 0.03 \\
Lignoceric (C24:0) & 6.21 & 0.04 \\
Saturated & 26.06 & 0.16 \\
Mono-unsaturated & 14.33 & 0.03 \\
Polyunsaturated & 59.61 & 0.12 \\
Sat/Insat* & $1 / 2.84$ & - \\
Ole/Lin & $1 / 4.16$ & - \\
\hline
\end{tabular}

${ }^{*}$ Relationship between the total of saturated and unsaturated fatty acids. ${ }^{* *}$ Relationship between total oleic and linoleic acids.

antioxidant activity and $\mathrm{EC}_{50}$ affected by Tamarindus indica $\mathrm{L}$. seeds extract were $75.93 \%$ and $204.72 \% \mu$ g. $\mathrm{mL}^{-1}$, respectively.

The concentration of total phenolic compounds contained $49.30 \mathrm{mg}$ of gallic acid equivalents per gram of Tamarindus indica L. extract. The extraction of phenolic compounds from natural products is strongly influenced by the solvent used. It has been observed that the higher the polarity of the extraction solvent, the greater the amount of extracted phenolic compounds (GAMÉZ-MEZA et al., 1999). In a study by Malacrida et al. (2007) using melon seeds, the content of phenolic compounds obtained was $20.9 \mathrm{mg}$ of gallic acid equivalents per gram of extract.

Regarding the oxidative stability, Tamarindus indica L. seed oil presented long hours of induction period (15.83) compared with edible oils such as soybean (12.47 hours) and sunflower (10.01 hours). This rate was similar to values obtained for tomato seeds oils (14.41 hours) and passion fruit (16.50 hours), as determined by Kobori and Jorge (2005).

Table 3 presents the fatty acids identified by gas chromatography, present in the lipid fraction of seeds. The profile of fatty acids indicates a higher content of linoleic (59.61\%), oleic (14.33\%) and palmitic (10.07\%) acids. The total amount of unsaturated fatty acids was $73.94 \%$, out of which $14.33 \%$ were monounsaturated acids and $59.61 \%$ were polyunsaturated fatty acids - having the linoleic acid as the main component.
Table 4. Means of tocopherols of Tamarindus indica L. seeds oil.

\begin{tabular}{lrc}
\hline Tocopherols $\left(\mathrm{mg} \mathrm{kg}^{-1}\right)$ & Mean & Standard deviation \\
\hline$\alpha$-Tocopherol & 12.36 & 0.16 \\
$\beta$-Tocopherol & 7.03 & 0.03 \\
$\gamma$-Tocopherol & 38.22 & 0.32 \\
$\delta$-Tocopherol & 0.16 & 0.01 \\
Total Tocopherol & 57.77 & 0.45 \\
Vitamin E $\left(\mathrm{UI.kg}{ }^{-1}\right)$ & 21.44 & 0.21 \\
\hline
\end{tabular}

The quality and digestibility of edible vegetable oils are determined by the amount and composition of unsaturated fatty acids. The presence of linoleic acid in adequate amounts is essential, since it is an essential fatty acid. The greater the amount of linoleic acid compared to oleic acid, the better the quality of the vegetable oil to prevent the formation of bad cholesterol (LDL) (EL-ADAWY; TAHA, 2001).

In umbu (imbu or Brazil plum) seeds oil, Borges et al. (2007) obtained a relationship between saturated and unsaturated fatty acids of $1 / 2,04$, indicating that the oil cannot be used in frying, since its stability and oxidative rancidity are related to the amount of unsaturated fatty acids. In this work, the relationship Sat/Insat was $1 / 2,84$.

According to Table 3, Tamarindus indica L. seeds oil presented an oleic acid/linoleic acid relation (Ole/Lin) of 1/4, 16 , close to the value found by El-Adawy and Taha (2001) for melon seeds oil $(1 / 3,3)$.

Table 4 presents the means for the isomers $\alpha_{-}, \beta_{-}, \gamma_{-}, \delta_{-}$, total tocopherols (mg. $\mathrm{kg}^{-1}$ ) and Vitamin E value (IU. $\mathrm{kg}^{-1}$ ) of Tamarindus indica $\mathrm{L}$. seeds oil. The seeds oil contains the isomers $\alpha$-, $\beta$-, $\gamma$-, $\delta$-tocopherol, as a total average value of $57.77 \mathrm{mg} \cdot \mathrm{kg}^{-1}$, which means that, compared to other fruit seed oils, Tamarindus indica L. seed oil is a good source of tocopherols. This source of tocopherol is common in highly unsaturated vegetable oils (81.20\%) such as baru seeds oil (TAKEMOTO et al., 2001).

The importance of the presence of tocopherols in relatively high concentrations in seeds oil is due to its antioxidant properties, which somehow contribute to the oxidative stability of polyunsaturated oils.

\section{Conclusions}

Through the development of this work, we could observe that among the analyzed macronutrients, the highest values were found for total carbohydrates (71.91\%). Furthermore, ethanolic extract of Tamarindus indica L. seed presents relevant antioxidant activity (75.93\%), but also great amount of total phenolic compounds (49.30 mg of gallic acid equivalents per gram of extract). Tamarindus indica L. seeds oil presented high oxidative stability (15.83 hours), showed significant total tocopherol content $\left(57.77 \mathrm{mg} \cdot \mathrm{kg}^{-1}\right)$ and a higher percentage of unsaturated fatty acids, especially linoleic acid (59.61\%), which is considered essential. The high unsaturation level of the seed oil favors its use either for edible purposes or as raw-material for the pharmaceutical and oleochemical industries, as long as the eventual harmful to health substances are removed. 


\section{Acknowledgements}

The authors are grateful to CAPES (Coordination for the Improvement of Higher Education Personnel), for the concession of the Masters scholarship, and to CNPq (National Council for Scientific and Technological Development), for the Research Productivity scholarship.

\section{References}

AMAROWICZ, R. et al. Free radical scavenging capacity and antioxidant activity of selected plant species from the Canadian prairies. Food Chemistry, v. 84, n. 4, p. 551-562, 2004. http://dx.doi.org/10.1016/S0308-8146(03)00278-4

AMERICAN OIL CHEMISTS SOCIETY - AOCS. Official methods and recommended practices of the American Oil Chemists' Society. Champaign: AOCS, 1993.

AMERICAN OIL CHEMISTS SOCIETY- AOCS. Official methods and recommended practices of the American Oil Chemists' Society. Champaign: AOCS, 1997.

ASSOCIATION OF OFFICIAL ANALYTICAL CHEMISTS - AOAC. Official and Tentative Methods of the AOAC International. Maryland: AOAC, 1995.

BAHIA (Estado). Secretaria da Agricultura, Irrigação e Reforma Agrária - SEAGRI. Cultura - Tamarindo. Disponível em: <www. seagri.ba.gov.br/Tamarindo.htm>. Acesso em: 29 dez. 2009.

BELDA, M. C. R.; POURCHET-CAMPOS, M. A. Ácidos graxos essenciais em nutrição: uma visão atualizada. Revista Ciência e Tecnologia de Alimentos, v. 11, n. 1, p.5-35, 1991.

BOCCO, A. et al. Antioxidant activity and phenolic composition of citrus peel and seed extracts. Journal of Agricultural and Food Chemistry, v. 46, n. 6, p. 2123-2129, 1998. http://dx.doi.org/10.1021/ jf9709562

BORGES, S. V. et al. Chemical composition of umbu (Spondias Tuberosa Arr. Cam) seeds. Química Nova, v. 30, n. 1, p. 49-52, 2007.

BRAND-WILLIAMS, W.; CUVELIER, M. E.; BERSET, C. Use of a free radical method to evaluate antioxidant activity. Lebensmittel - Wissenschaft und Technologie, v. 28, n. 1, p. 25-30, 1995.

CURI, R. et al. Entendendo a gordura - os ácidos graxos. São Paulo: MANOLE, 2002.

EL-ADAWY, T. A.; TAHA, K. M. Characteristics and composition of different seed oils and flours. Food Chemistry, v. 74, n. 1, p. 47-54, 2001. http://dx.doi.org/10.1016/S0308-8146(00)00337-X

FERNANDES , J. B. et al. Extrações de óleos de sementes de citros e suas atividades sobre a formiga cortadeira Atta sexdens e seu fungo simbionte. Química Nova, v. 25, n. 6B, p. 1091-1095, 2002. http://dx.doi.org/10.1590/S0100-40422002000700009

GAMÉZ-MEZA, N. et al. Antioxidant activity in soybean oil of extracts from Thompson grape bagasse. Journal of the American Oil Chemists' Society, v. 76, n. 12, p. 1445-1447, 1999.
HARTMAN, L.; LAGO, R. C. A. Rapid preparation of fat acids methil esters. Laboratory and Practy, v. 22, p. 475-476, 1973.

JAYAPRAKASHA, G. K.; SINGH, R. P.; SAKARIAH, K. K. Antioxidant activity of grape seeds (Vitis vinifera) extracts on peroxidation models in vitro. Food Chemistry, v. 73, n. 3, p. 285-290, 2001. http://dx.doi.org/10.1016/S0308-8146(00)00298-3

JUNG, M. Y.; MIN, D. B. Effects of $\alpha, \gamma$, e $\delta$ tocopherols on oxidative stability of soybean oil. Journal of Food Science, v. 55, n. 5, p. 1464-1465, 1990. http://dx.doi.org/10.1111/j.1365-2621.1990. tb03960.x

KAMAL-ELDIN, A.; APPELQVIST, L. A. The chemistry and antioxidant properties of tocopherols and tocotrienols. Lipids, v. 31, n. 7, p. 671-701, 1996. PMid:8827691. http://dx.doi.org/10.1007/ BF02522884

KOBORI, C. N.; JORGE, N. Caracterização dos óleos de algumas sementes de frutas como aproveitamento de resíduos industriais. Ciência e Agrotecnologia, v. 29, n. 5, p. 1008-1014, 2005. http:// dx.doi.org/10.1590/S1413-70542005000500014

KOMUTARIN, T. et al. Extract of the seed coat of Tamarindus indica inhibits nitric oxide production by murine macrophages in vitro and in vivo. Food and Chemical Toxicology, v. 42, n. 4, p. 649-658, 2004. PMid:15019190. http://dx.doi.org/10.1016/j.fct.2003.12.001

MALACRIDA, C. R. et al. Composição química e potencial antioxidante de extratos de sementes de melão amarelo em óleo de soja. Revista Ciência Agronômica, v. 38, n. 4, p. 372-376, 2007.

POMPÉIA, C.; PROCÓPIO, J.; CURI, R. Fatty acids and the immune system. Revista Brasileira de Ciências Farmacêuticas, v. 35, n. 2, p. $165-194,1999$.

SIDDHURAJU, P. Antioxidant activity of polyphenolic compounds extracted from defatted raw and dry heated Tamarindus indica seed coat. Food Science and Technology, v. 40, n. 6, p. 982-990, 2007.

SINGLETON, V. L.; ROSSI JR, J. A. Colorimetry of total phenolics with phosphomolybdic-phosphotungstic acid reagents. American Journal of Enology and Viticulture, v. 16, n. 3, p. 144-158, 1965.

TAKEMOTO, E. et al. Composição química da semente e do óleo de baru (Dipteryx alata Vog.) nativo do Município de Pirenópolis, Estado de Goiás. Revista do Instituto Adolfo Lutz, v. 60, n. 2, p. 113-117, 2001.

TORRES, J. L. et al. Valorization of grape (Vitis vinifera) byproducts. Antioxidant and biological properties of polyphenolic fractions differing in procyanidin composition and flavonol content. Journal of Agricultural and Food Chemistry, v. 50, n. 26, p. 7548-7555, 2002. PMid:12475269. http://dx.doi.org/10.1021/jf025868i

TSUDA, T. et al. Antioxidative components isolated from the seed of tamarind (Tamarindu indica L.). Journal of Agricultural and Food Chemistry, v. 42, n. 12, p. 2671-2674, 1994. http://dx.doi. org/10.1021/jf00048a004 